\title{
ENTRE O PROFESSOR PÚBLICO E O PENSADOR PRIVADO: A FIGURA DO MESTRE EM DELEUZE
}

\author{
BETWEEN THE PUBLIC TEACHER AND THE PRIVATE THINKER: \\ THE FIGURE OF THE MASTER IN DELEUZE
}

\section{ENTRE EL PROFESOR PÚBLICO Y EL PENSADOR PRIVADO: LA FIGURA DEL MAESTRO EM DELEUZE}

Christian Fernando Ribeiro Guimarães Vinci ${ }^{1}$

\section{RESUMO}

Gilles Deleuze, embora pouco ou nada tenha escrito sobre educação, concedeu uma especial atenção ao conceito de aprendizado. Concebido como um processo involuntário disparatado por um encontro violento com signos heterogêneos que nos levam a pensar, a noção deleuziana de aprendizado parece não conceder espaço para qualquer figura imbuída de autoridade professoral. A aprendizagem, em Deleuze, apresentar-se-ia como um processo imanente que, em tese, prescindiria de mestres ou professores. Não obstante isso, em diversos momentos de sua obra, o filósofo francês chegou a defender a importância de possuirmos mestres ou professores. Buscando elucidar essa aparente contradição, esse artigo procurará pensar como a figura do mestre convive no interior da noção de aprendizado forjada por Deleuze. Para tanto, resgataremos a distinção deleuziana entre o professor público e o pensador privado, tomando-as como disparadoras para pensarmos a figura do mestre. Acreditamos que tal distinção, contrapondo-se às noções formuladas por Immanuel Kant de uso privado e uso público da razão, possibilitaria pensarmos o mestre como aquele responsável por romper com o universo judicativo kantiano e capaz de ofertar um vislumbre de um pensamento sem qualquer lastro judicativo ou representativo - intento último da filosofia de Deleuze e Deleuze-Guattari.

PALAVRAS-CHAVE: Gilles Deleuze. Filosofia da Educação. Pensamento Filosófico.

\section{ABSTRACT}

Gilles Deleuze paid special attention to the concept of learning. Conceived as an involuntary process initiated by a violent encounter with heterogeneous signs that lead us to think, the deleuzian notion of learning seems to grant no space for any figure imbued with professorial authority. Learning, in Deleuze, would be presented as an immanent process which, in theory, would dispense figures such as those masters or teachers. Nevertheless, in several moments of his work, the french philosopher defended the importance of having masters or teachers. In order to elucidate this apparent contradiction, this article will try to think how the figure of the master coexists within the notion of learning forged by Deleuze. To do so, we will rescue the Deleuzian distinction between the public teacher and the private thinker, taking them as triggers to think the figure of the master. We believe that distinction, as opposed to Immanuel Kant's notions of private use and public use of reason, would allow us to think of the master as responsible for breaking with the kantian judicial universe and capable of offering a glimpse of a thought without any judicial ballast or representative - the ultimate intent of the philosophy of Deleuze and Deleuze-Guattari.

KEYWORDS: Gilles Deleuze. Philosophy education. Thinking.

${ }^{1}$ Doutorando em Filosofia da Educação pela Universidade de São Paulo (USP) - São Paulo, SP - Brasil. Assistente de Pesquisa - Escritório de Apoio à Pesquisa - Universidade Federal de São Paulo, (EAP-UNIFESP) São Paulo, SP - Brasil. E-mail: christian.guimaraes.vinci@gmail.com

Submetido em: 03/08/2017 - Aceito em: 15/02/2018

(C) ETD- Educação Temática Digital Campinas, SP $\quad$ v.20 $\quad$ n.4 $\quad$ p. 1017-1035 out./dez. 2018




\section{RESUMEN}

Gilles Deleuze, aunque poco o nada ha escrito sobre educación, concedió una especial atención al concepto de aprendizaje. El concepto desencadenante de aprendizaje parece no conceder espacio para cualquier figura imbuida de autoridad profesoral. El aprendizaje, en Deleuze, se presentaría como un proceso inmanente que, en tesis, prescindía de maestros o profesores. A pesar de eso, en diversos momentos de su obra, el filósofo francés llegó a defender la importancia de poseer maestros o profesores. En busca de elucidar esa aparente contradicción, ese artículo procurará pensar cómo la figura del maestro convive en el interior de la noción de aprendizaje forjada por Deleuze. Para ello, rescataremos la distinción deleuziana entre el profesor público y el pensador privado, tomándolas como disparadoras para pensar la figura del maestro. Creemos que tal distinción, contraponiéndose a las nociones formuladas por Immanuel Kant de uso privado y uso público de la razón, posibilitaríamos pensar al maestro como aquel responsable de romper con el universo judicativo kantiano y capaz de ofrecer un vislumbre de un pensamiento sin ningún lastre judica 0 representativo intento último de la filosofía de Deleuze y Deleuze-Guattari.

PALABRAS CLAVE: Gilles Deleuze. Filosofía de la Educación. Pensamiento filosófico.

\section{INTRODUÇÃO}

Daniel Lins, no opúsculo Juízo e Verdade em Deleuze (2004), ao comentar o peculiar estatuto do juízo no interior da filosofia de Gilles Deleuze, atenta para o modo como o pensador francês o concebe sob os auspícios da clínica mais do que da crítica. Julgar, para o autor de Diferença e Repetição, não implicaria avaliar o real a partir da sua adequação ou não a um campo transcendente que, pretensamente, deveria lhe servir de norte, mas, antes e de modo involuntário, configuraria uma atitude face a um estado de coisas. Compreendido como uma espécie de resposta sensório-motora, o julgamento, sob a égide da clínica, expressaria uma avaliação imanente dos modos de existência implicados em uma situação. O juízo, por conseguinte, seria uma espécie de gesto - sensível mais do que racional - capaz de permitir a um vivente potencializar o seu poder de afetar e de ser afetado $^{2}$. Enquanto em uma concepção mais tradicional, ainda conforme Lins (2004), o juízo diria respeito a distinção entre o verdadeiro e ao falso ou ao bom e ao mau, na acepção deleuziana, ele apontaria para a possibilidade de criarmos outros espaços de experiência. A vida, nesse diapasão clínico mais do que crítico, confundir-se-ia com o pensar e, imanentes, ambos ensejariam inauditos horizontes de experimentação; ou, nos dizeres do comentador, abririam espaço para a vivência de um real-outro, não condicionado por nenhum alhures. Sintetizando essa discussão, diz-nos Lins (2004, p. 32-3):

\footnotetext{
${ }^{2}$ Não surpreende, portanto, a entusiasmada defesa deleuziana de que o grande pensador crítico foi Friedrich Nietzsche e não Immanuel Kant. Nos dizeres do filósofo francês (Deleuze, 1976), Nietzsche teria sido o filósofo crítico por excelência, pois aproximou a razão do sensível e buscou operar uma outra sensibilidade - intento derradeiro de qualquer empreendimento crítico nos dizeres de Deleuze.
}

C ETD- Educação Temática Digital Campinas, SP $\quad$ v.20 $\quad$ n.4 $\quad$ p. 1017-1035 out./dez. 2018 
Pode-se, contudo, se tal for o desejo, guardar o termo juízo, mas somente se compreendido não como uma faculdade, mas, como uma atitude a afetar e a ser afetado pela vida. O problema com a concepção comum do juízo, que consiste em dele fazer uma faculdade para reconhecer o verdadeiro do falso, é antes seu poder anestesiante que separa o pensamento da vida, confinando-o no universo fechado - entre quatro paredes - e estéril da consciência e que, se acreditando autônomo, impõe sua forma ao real e não exprime nada além da sua reprodução. (...) O perigo - aqui há de fato um sério problema - com as filosofias do juízo se manifesta na sua confiança absoluta na consciência e na sua capacidade de verdade. (...) O real não é pois nem verdadeiro nem falso - axiomas fundamentais do juízo - mas um real-outro, compreendido por Deleuze, sob os passos de Bergson, como a produção do novo, do diferente, para além do que havia de eterno nesse mundo. (grifos do autor)

Essa peculiar concepção, densamente trabalhada por Deleuze (2007), não abala apenas os alicerces daquelas tradicionais filosofias do juízo, mas instaura ardilosas questões em campos de saber diversos, mormente naqueles acostumados a operar tendo em mente algum campo suprassensível - seja um valor aprioristicamente estabelecido ou alguma finalidade a ser atingida. Para os pesquisadores do campo educacional, sequer é preciso dizer, essa outra concepção de juízo faz desabar o sustentáculo de nosso sólido - e moderno - edifício pedagógico. Como conceber uma educação que não opere sob a chancela dos juízos, que não visa separar o bom do mau ou o verdadeiro do falso? Ou, ainda, pensar uma educação pouco preocupada em aplicar um determinado preceito ou em atingir um determinado fim? O que nos restaria ensinar e qual aluno acabaríamos por formar?

Esse outro modo de pensar o juízo, como nota Lins (2004), evoca uma outra noção de aprendizado, na qual uma vida, na imanência de seus encontros, coloca as suas próprias demandas e acaba por dirigir o processo de aprendizagem. Os signos produzidos por esses embates, portanto, norteariam o processo. Sobre essa questão, diz-nos Deleuze (2010, p. 4):

\begin{abstract}
Aprender diz respeito essencialmente aos signos. Os signos são objeto de um aprendizado temporal, não de um saber abstrato. Aprender é, de início, considerar uma matéria, um objeto, um ser, como se emitissem signos a serem decifrados, interpretados. Não existe aprendiz que não seja "egiptólogo" de alguma coisa. Alguém só se torna marceneiro tornando-se sensível aos signos da madeira, e médico tornando-se sensível aos signos da doença. A vocação é sempre uma predestinação com relação a signos. Tudo que nos ensina alguma coisa emite signos, todo ato de aprender é uma interpretação de signos ou de hieróglifos.
\end{abstract}

Não há voluntarismo por parte de um vivente, pois este jamais pode realmente escolher o que deseja aprender ou não - são sempre os violentos e contingenciais embates com signos heterogêneos que esboçam um caminho para o aprendiz. Não se sabe de antemão que signo resultará de um determinado encontro, por esse motivo a experimentação é uma diretriz importante para todos aqueles que optam por pensar o

(C) ETD-Educação Temática Digital Campinas, SP $\quad$ v.20 $\quad$ n.4 $\quad$ p. 1017-1035 out./dez. 2018


aprendizado a partir de um matiz deleuziano. Os juízos, caso queiramos experimentar os encontros sem mediações de nenhuma ordem - realizar experimentações conforme a acepção de Deleuze, portanto -, devem ser banidos e permitir a cada qual construir um espaço de imanência próprio. Caso isso não aconteça, nosso espaço de experiência acabará mediado por valores transcendentes que definirão, aprioristicamente, o que é bom ou não de ser vivenciado, o que deve ser considerado verdadeiro e o que seria falso. A experimentação restaria calada, pois. Por esse motivo, ainda conforme Deleuze (2010), aprender demanda uma perda de tempo considerável e uma entrega absoluta aos encontros fortuitos dos quais somos vítimas, a fim de, assim, fazermos calar os juízos.

\begin{abstract}
Quando pensamos que perdemos nosso tempo, seja por esnobismo, seja por dissipação amorosa, estamos muitas vezes trilhando um aprendizado obscuro, até a revelação final de uma verdade desse tempo que se perde. Nunca se sabe como uma pessoa aprende; mas, de qualquer forma que aprenda, sempre por intermédio de signos, perdendo tempo, e não pela assimilação de conteúdos objetivos. Quem sabe como um estudante pode tornar-se repentinamente "bom em latim", que signos (amorosos ou até mesmo inconfessáveis) Ihe serviriam de aprendizado? Nunca aprendemos alguma coisa nos dicionários que nossos professores e nossos pais nos emprestam. O signo implica em si a heterogeneidade como relação. Nunca se aprende fazendo como alguém, mas fazendo com alguém, que não tem relação de semelhança com o que se aprende. (Deleuze, 2010, p. 21)
\end{abstract}

Essa concepção de aprendizado, tal qual exposta acima, coloca inúmeros problemas para os educadores e para os pesquisadores do campo educacional interessados em trabalhar a partir do referencial teórico deleuziano. Ora, sabemos que, em Educação, o conceito de aprender é costumeiramente relacionado com o verbo ensinar (Castello; Mársico, 2007). Essa relação, vista como natural por muitos, implica que aprender diz respeito a aquisição de um saber que residiria alhures - no professor ou no mundo das ideias, não importa - e que seria transmitido por algo ou alguém, um livro ou um professor. Educar, nessa seara mais tradicional, significa orientar, guiar ou, ainda, formar. Aprender seria a contraparte do ensinar, e ambos trabalhariam visando atingir certo resultado ou objetivo estabelecido de antemão. Ao trabalharmos com o conceito forjado por Deleuze, portanto, colocamo-nos em um espectro diametralmente oposto a este presente na área.

Não obstante contrapor-se às visões mais tradicionais, os estudos educacionais de acento deleuziano têm aumentado em número nos últimos anos e demonstrado sua relevância para pensarmos a Educação (Marinho, 2014; Vinci, 2014). Discussões como a supramencionada, envolvendo uma explanação sobre o conceito de aprendizado forjado por Deleuze, já não possuem qualquer ineditismo ou raridade. Os pesquisadores em Educação e os educadores acostumam-se cada vez mais com o vocabulário deleuziano, bem

(C) ETD-Educação Temática Digital Campinas, SP $\quad$ v.20 $\quad$ n.4 $\quad$ p.1017-1035 out./dez. 2018 
como com as temáticas trabalhadas por sua filosofia - escrita ou não em parceria com o psicanalista Félix Guattari. Por esse motivo, esse artigo abster-se-á de discutir noções deleuzianas como a de aprendizado, trabalhadas aqui e acolá por muitos outros pensadores (Schérer, 2005; Gallo, 2012), e procurará pensar uma temática ainda pouco explorada, qual seja: o papel do professor ou do mestre - se é que há algum papel - no interior desse universo forjado por Deleuze, no qual os juízos deixam de vigorar.

Não ignoramos que essa temática, em um primeiro momento, possa soar caduca, pois se o aprendizado se dá por intermédio de signos, qualquer professor ou mestre perderia sua razão de ser. De fato, assim o é. Não ignoramos que, ao abolirmos os juízos e privilegiarmos os encontros ocorridos em um processo de aprendizado imanente, pouco resta a ser discutido quanto ao papel que um professor poderia vir a adquirir nesse processo. Contudo, é preciso um maior vagar e uma maior atenção para certas pistas deixadas pelo próprio Deleuze, autor que, certa feita, sentenciou: "gerações sem 'mestres' são uma tristeza" (Deleuze, 2006, p. 107) e prosseguiu defendendo a necessidade de professores de todas as ordens. O uso de aspas indica que não se trata de uma qualquer concepção, mas ainda assim o filósofo francês concedeu um lugar para a estranha figura do mestre. Resta-nos, afinal, saber qual é esse lugar.

Para tanto, propomos pensar a figura deleuziana do mestre a partir da distinção, estabelecida pelo filósofo em inúmeras de suas obras, entre dois personagens conceituais, quais sejam: o professor público e o pensador privado. Essas figuras, costumeiramente evocadas por Deleuze e Deleuze-Guattari ao tratar da função do idiota em filosofia, evocam um outro - e já considerada clássico - binômio, este da lavra de Immanuel Kant, que estabelece uma diferença entre um uso público e um uso privado da razão. Essa importante discussão kantiana, recuperada por Michel Foucault (2008) e outros tantos autores, possui um papel fulcral na História da Filosofia de acordo com Deleuze e Guattari (2008), uma vez que instaura uma concepção dogmática ou uma imagem de pensamento que nos impede de vivenciarmos os encontros em sua imanência ao colocar uma série de condicionantes para que possamos pensar. O mestre, acreditamos, seria aquele que rompe com o universo judicativo kantiano e possibilita aos demais vislumbrarem uma oportunidade de exercermos um pensamento outro, sem qualquer lastro judicativo ou representativo. Esse artigo, por fim, procurará esclarecer como essa figura convive no interior da noção de aprendizado deleuziana e deleuzo-guattariano. 


\section{PARA ALÉM DO USO PÚBLICO E DO USO PRIVADO DA RAZÃO}

Há quatro textos no corpus deleuziano dedicados a discutir as figuras, ou personagens conceituais, do professor público e do pensador privado e sua intricada relação. O primeiro, datado de 1964 e intitulado "Ele foi meu mestre" (Deleuze, 2006), foi publicado por Deleuze na revista Arts por ocasião da recusa do Nobel por parte de Jean-Paul Sartre. 0 segundo, remete-nos à uma breve passagem de Diferença e Repetição, logo em sua introdução, no momento no qual Deleuze (1988) opta por discutir um programa para uma filosofia da repetição a partir da tríade Kierkegaard-Nietzsche-Péguy. O terceiro está presente em Mil Platôs, obra escrita em parceria com Guattari e publicado em 1980, no platô intitulado 1227 - Tratado de nomadologia: a máquina de guerra (Deleuze; Guattari, 2008). E o último, por fim, encontra-se no excerto "Exemplo V" alocado no interior do capítulo Os Personagens Conceituais da obra O que é a Filosofia? (Deleuze; Guattari, 1992), lançada em 1991. Tratam-se, portanto, de textos escritos em épocas distintas e que, não obstante, guardam algumas similaridades. Depreende-se que essa discussão não é algo meramente acessório no pensamento deleuziano e/ou deleuzo-guattariano, mas possuí relevância no interior de seu edifício filosófico.

Antes de prosseguirmos com a apresentação e análise desses textos, convém notar que essas personagens retomam e reinventam uma discussão filosófica mais antiga, qual seja: aquela referente ao uso público e ao uso privado da razão, formulada por Immanuel Kant em seu opúsculo $O$ que é o Esclarecimento?. Publicado em setembro de 1784 na Berlinischen Monatsschrift, como resposta a uma provocação lançada pelo pastor Zöllner em uma nota de pé de página desse jornal, esse pequeno texto rendeu e rende muitas discussões. Michel Foucault (2008), certa feita, asseverou acerca desse escrito kantiano: "Texto menor, talvez. Mas me parece que, com ele, entra discretamente na história do pensamento uma questão que a filosofia moderna não foi capaz de responder, mas da qual ela nunca conseguiu se desembaraçar" (p. 335). O filósofo francês, nesse célebre texto intitulado $O$ que são as Luzes?, refere-se à questão acerca das possibilidades da filosofia interpelar o tempo presente e apontar uma saída de nosso estado de menoridade - sendo este definido pelo próprio Kant como "a incapacidade de se servir de seu próprio entendimento sem a condução de outrem" (2011, p. 23). Essa questão sobre ser ou não conduzido por outrem, bem como suas implicações políticas e cognitivas, levou o filósofo alemão a distinguir um uso público de um uso privado da razão - motivo que nos interessa diretamente na discussão empreendida por nós. 
Kant (2011, p. 24-25) reconhece a dificuldade que é para "todo e qualquer ser humano particular" desembaraçar-se de sua menoridade, naturalizada há muito por aqueles que preferem ter um guia de conduta do que conduzirem a si próprios, e aponta o quão benéfico seria ser esclarecido no interior de um grupo mais amplo, composto por indivíduos livres e capazes de utilizar sua razão sem freios de nenhuma espécie.

\begin{abstract}
Poucos são aqueles que conseguem se desembaraçar da menoridade por meio do próprio cultivo de seu espírito e ainda trilhar um caminho seguro. (...) É antes possível, porém, que um público se esclareça por si mesmo; é até praticamente inevitável se apenas lhe deixarmos ser livre. Pois sempre há aí aqueles que pensam por si mesmos, até mesmo entre os referidos tutores da grande multidão, os quais, assim que tiverem eles mesmos deixados para trás o jugo da menoridade difundirão ao redor de si o espírito de uma estima racional pelo próprio valor e pela vocação de todo ser humano para pensar por si mesmo. (Kant, 2011, p. 25)
\end{abstract}

Segue-se, assim, que os homens devem ter plena liberdade de fazerem um uso público de sua razão, sendo este uso compreendido por Kant como aquele "que alguém, enquanto erudito, faz diante de todo o público do mundo letrado" (2011, p. 27). Em contrapartida, um uso privado seria "aquele que o erudito pode fazer de sua razão em um específico cargo civil ou em uma função que foram confiados a ele" (Kant, 2011, p. 27). Portanto, o uso público implicaria utilizar a razão livremente quando no interior de um grupo restrito, composto por homens letrados e, em tese, capazes de serem conduzidos cada qual por si próprio; enquanto o uso privado, por sua vez, diria respeito ao modo como esse mesmo erudito utiliza sua razão em um cargo civil ou ao assumir uma função que exigiria apenas obediência. Ora, em outros termos, Kant defende a liberdade de pensamento para todo e qualquer homem erudito no interior de uma congregação mais ampla composta por iguais, o dito público, e, para as demais situações, a coação.

Desse modo, um professor deveria se limitar ao uso privado de sua razão, pois, quando no exercício de sua função, ele não pode dar livre vazão aos seus julgamentos, devendo se submeter às tarefas que lhe forma impostas - educar, formar etc. - e calar o seu pensamento. Os alunos tampouco poderiam fazer um uso público, uma vez que devem aceitar serem guiados por outrem e nada mais. O exemplo privilegiado por Kant (2011), no caso do uso público, é sempre aquele do sábio que, independentemente da função que ocupa, fala por meio de seus escritos para outros tantos indivíduos. Portanto, para o filósofo alemão, apenas nessa restrita comunidade erudita de escritores, o público kantiano, é possível o esclarecimento. Foucault (2008), atento comentador, argumenta: 
Seria possível pensar que nada há aí de muito diferente do se entende, desde o século XVI, por liberdade de consciência: o direito de pensar como se queira, desde que se obedeça como é preciso. Ora, é ali que Kant faz intervir uma outra distinção e a faz intervir de uma maneira bem surpreendente. Trata-se da distinção entre o uso privado e o uso público da razão. Mas ele acrescenta logo a seguir que a razão deve ser livre em seu uso público e que deve ser submissa em seu uso privado. (...) Kant não pede que se pratique uma obediência cega e tola: mas que se faça um uso da razão adaptado a essas circunstâncias determinadas; e a razão deve submeter-se então a esses fins particulares. Não pode haver, portanto, aí [uso privado], uso livre da razão. Em compensação, quando se raciocina apenas para fazer uso de sua razão, quando se raciocina como ser racional (e não como peça de uma máquina), quando se raciocina como membro da humanidade racional, então o uso da razão deve ser livre e público. (p. 339)

O mestre, ou aquele responsável por tirar o homem de sua menoridade, só cumpre essa sua tarefa quando no uso público de sua razão. Ora, Deleuze e Guattari (2008), ao distinguirem uma ciência nômade de uma ciência régia ou de Estado, notam como essa concepção kantiana trabalha a favor daquilo que os autores denominaram de uma imagem de pensamento. Imagem esta que dita, conforme nos lembra Deleuze (1988), o bom e o mau pensamento, bem como o verdadeiro e o falso na ordem do pensar. Uma imagem moral, se assim o quiserem, que, em Mil Platôs, aparece sob a chancela estatal.

\footnotetext{
Obedece sempre, pois quanto mais obedeceres, mais serás senhor, visto que só obedecerás a razão pura, isto é, a si mesmo... Desde que a filosofia se atribuiu ao papel de fundamento, não parou de bendizer os poderes estabelecidos, e decalcar sua doutrina das faculdades dos órgãos de poder do Estado. O senso comum, a unidade de todas as faculdades como centro do Cogito, é o consenso do Estado levado ao absoluto. Essa foi notadamente a grande operação da "crítica" kantiana, retomada e desenvolvida pelo hegelianismo. Kant não parou de criticar os maus usos para melhor bendizer a função. Não deve surpreender que o filósofo tenha se tornado professor público ou funcionário de Estado. Tudo está acertado a partir do momento em que a forma-Estado inspira uma imagem de pensamento. E viceversa. (Deleuze; Guattari, 2008, p. 45)
}

Ao trabalhar a favor de uma determinada concepção de pensamento, pautada em valores transcendentais estabelecidas pelo senso comum, Kant acabou por calar a imanência que, para Deleuze e Guattari, conduziriam todo e qualquer aprendizado, todo e qualquer pensamento. O pensamento, nos dizeres dos autores (2008), possuiria uma forma de exterioridade, ou uma força sempre exterior a si que possibilitaria a sua emergência - o encontro com os signos -, capaz de destruir "a imagem e suas cópias, o modelo e suas reproduções, toda possibilidade de subordinar o pensamento a um modelo de Verdadeiro, do Justo ou do Direito" (Deleuze; Guattari, 2008, p. 47). Não há prescrição, receita ou coerção capazes de controlar o processo do pensar; diferenciar, portanto, um uso público e bom - de um uso privado - e mau - da razão soaria, no mínimo, despropositado. Deleuze

C ETD-Educação Temática Digital Campinas, SP $\quad$ v.20 $\quad$ n.4 $\quad$ p.1017-1035 out./dez. 2018


e Deleuze-Guattari, ao forjarem uma distinção entre um professor público e um pensador privado, recuperam a distinção kantiana para subvertê-la.

O professor público, nesse diapasão deleuziano e deleuzo-guattariano, não seria aquele que faz uso público de sua razão. Termos como uso público e uso privado, na verdade, sequer aparecem em Deleuze e Deleuze-Guattari, que provavelmente os evitam a fim de não adentrarem em uma contenda dialética. Não obstante a recusa em recuperar a terminologia kantiana, esses personagens criados pelos filósofos franceses problematizam o campo aberto pela discussão empreendida por Kant em seu opúsculo e operam uma quebra daquele lastro moral da imagem de pensamento kantiana.

\section{PROFESSOR PÚBLICO E O PENSADOR PRIVADO}

O professor público não necessariamente é aquele que faz um uso público de sua razão, como poderia fazer-nos crer os termos empregados, mas o contrário. Em $O$ que é a Filosofia?, Deleuze e Guattari (1992) escrevem:

O professor não cessa de remeter a conceitos ensinados (o homem-animal racional), enquanto o pensador privado forma um conceito com forças inatas que cada um possui de direito por sua conta (eu penso). Eis um tipo muito estranho de personagem, aquele que que pensar e pensa por si mesmo, pela "luz natural". (p. 83)

A distinção entre o professor público e o pensador privado, nessa derradeira obra de sua lavra, serve de ocasião para Deleuze e Guattari discutirem a importância para a filosofia do idiota ${ }^{3}$. Os pensadores franceses apontam algumas mudanças na figura do idiota ao longo da história e as decorrências dessa modificação para as personagens supramencionadas. Para Deleuze e Guattari é importante notar como o idiota, em certa altura, deixa de querer apenas ser uma espécie de pensador privado que quer pensar por si mesmo, procurando o verdadeiro ou a "luz natural", e passa a buscar o absurdo. Há, portanto, uma reconfiguração do pensador privado em sua oposição ao professor público ao longo da história.

\footnotetext{
${ }^{3}$ Para uma leitura dessa personagem conceitual deleuzo-guattariana remetemos o leitor à (Mengue, 2013; Vinci, 2017). 
$\mathrm{O}$ antigo idiota queria o verdadeiro, mas o novo quer fazer do absurdo a mais alta potência do pensamento, isto é, criar. O antigo idiota queria não prestar contas senão à razão, mas o novo idiota, mais próximo de Jó que de Sócrates, quer que se lhe preste contas de "cada vítima da história", esses não são os mesmos conceitos. Ele não aceitará jamais as verdades da História. O antigo idiota queria dar-se conta, por si mesmo, do que era compreensível ou não, razoável ou não, perdido ou salvo, mas o novo idiota quer que lhe devolvam o perdido, o incompreensível, o absurdo. Seguramente não é o mesmo personagem, houve uma mutação. E, todavia, um fio tênue une os idiotas, como se fosse necessário que o primeiro perdesse a razão para que o segundo reencontrasse o que o outro tinha perdido a princípio, ganhando-a. (Deleuze; Guattari, 1992, p. 84-85)

Tanto o antigo idiota quanto o novo são apresentados como pensadores privados, mas não são aqueles que, por portarem um tal título, utilizar-se-iam de um uso privado de sua razão. Eles não obedecem a ninguém e não estão condicionados pela situação em que se encontram, apenas buscam a "luz natural" ou o absurdo. São livres em seu pensar. Conforme nota Deleuze em Diferença e Repetição (1988), outro livro no qual essa personagem também aparece, o pensador privado é um pensador-cometa, amoral e antiético por excelência, ou seja, é aquele que, no exercício de sua liberdade, rompe com todo e qualquer preceito estabelecido de antemão. Diferentemente do professor público, responsável por ensinar ou remeter a conceitos prontos e, por esse motivo, valer-se apenas do uso privado de sua razão. Ainda em Diferença e Repetição, o professor público nos é apresentado como uma espécie de "doutor da lei, cujo discurso de segunda mão procede por mediação e tem como fonte moralizante a generalidade dos conceitos" (Deleuze, 1988, p. 27).

Percebemos, desse modo, como essa discussão coaduna-se com aquela mais ampla acerca da relação entre verdadeiro e falso e bom e mal no interior daquilo que muitos denominaram de faculdade de julgar. De fato, em Kant, a distinção entre um uso público e um uso privado opera em consonância com uma visão moral dos juízos. As coações e o estabelecimento de certas condições para que o pensamento possa se exercer de maneira livre, nesse sentido, atestam a importância do estabelecimento de pressupostos que permitam a um vivente pensar adequadamente. Em Deleuze, com sua concepção particular de juízo, essa configuração acabaria por calar o pensamento em todas as suas potencialidades, uma vez que esse seria afastado da vida corriqueira e, portanto, dos encontros inerentes a esta. Por esse motivo, ultrapassar essa imagem moral é uma tarefa ética para Deleuze e Deleuze-Guattari, autores que se empenharam em problematizar e elidir com aquela tradicional distinção kantiana. Vejamos de qual maneira. 
Em linhas gerais, poder-se-ia afirmar que o uso público da razão kantiano, transmutar-se-ia, em Deleuze e Guattari, numa força criativa inata ao pensador privado. Esta figura corresponderia, grosso modo, ao erudito kantiano, mas para os pensadores franceses ele seria apenas um idiota, ou aquele que não precisa de nenhuma condição para exercer seu pensamento em liberdade. O uso privado kantiano, por sua vez, remeteria à figura do professor público deleuzo-guattariano, aquele que se submete ao jugo de um saber e/ou função e, por esse motivo, não cria nenhum conceito ou pensa por si próprio. A grande questão ou distorção, a nosso ver, é que o pensador privado deleuzo-guattariano não depende de um público para as suas experimentações de pensamento. Mais próximo de Jó, aquele que sofre só as suas angústias, do que de Sócrates, o professor por excelência, o pensador privado não submete o seu pensar a nada ou a ninguém. Ele desobedece ao ousar pensar, ao buscar o absurdo que lhe é de direito. O professor público, em contrapartida, obedece a tudo e a todos mesmo quando crê estar pensando livremente.

Essa distinção deleuzo-guattariana é importante na medida em que os aproxima de uma concepção de que a filosofia é uma atividade criativa e não reflexiva. Um erudito que se debruça sobre um conceito e o apresenta aos seus pares - à um público, portanto -, intuindo com isso elucidá-los quanto à importância dessa noção para que a comunidade de seres racionais possa sair de sua menoridade, não passaria, para Deleuze e Guattari (1992), de um professor público. Assim, alguém poderia piamente acreditar estar utilizando publicamente sua razão, em termos kantianos, quando na verdade não deixa de obedecer a certos preceitos e condições que o aproximam muito mais daquilo que o próprio Kant denominaria de pensador privado. Ainda condicionado por uma série de imperativos, que Ihe ditam o que significa pensar, esse indivíduo reflete sobre conceitos já dados, mas não cria novas noções e tampouco experimenta pensar-viver sem mediações de nenhuma ordem. Em Deleuze e Guattari são outras as coordenadas sobre o que significa pensar, e essa diferença em relação à Kant acaba por produzir essa confusão de termos, embora os conteúdos da discussão se assemelhem sobremaneira. Para os primeiros, os encontros contingenciais e a imanência entre pensamento e vida são os guias da experimentação; para o segundo, um uso livre da razão só deve acontecer quando atende uma série de preceitos. Em Deleuze e Guattari, não há hora ou local para o surgimento do pensamento ou para a criação conceitual, embora ambas as ocasiões sejam raras, e isso os diferencia do autor de $O$ que é o Esclarecimento?. 
Esse binarismo deleuzo-guattariano - professor público versus pensador privado -, difícil de ser apreendido em sua complexidade, ao fim acaba por implodir o binarismo esboçado outrora por Kant em seu texto ${ }^{4}$. O uso público da razão não necessariamente ocorre ali onde Kant acredita, e tampouco o uso privado. A razão liberta de todas as amarras, desobediente e anárquica, não se restringe ao espaço seleto de um público, mesmo que este seja toda a comunidade de seres racionais. O idiota, nesse sentido, é a grande e radical figura esboçada por Deleuze e Guattari, responsável por fazer elidir o edifício kantiano. Conforme nota Phillipe Mengue (2013), o grande exemplo do idiota fornecido pelos pensadores franceses é Bartleby, o escrivão de Hermam Melville que, caso adotemos a concepção kantiana, não passaria de alguém apto apenas à utilização privada de sua razão. O que o escrivão faz, ao utilizar a sua atípica fórmula, é colocar em circulação um pensamento disruptivo que the surgiu a partir de forças inatas que o levaram a pensar. O pensamento, assim, ocorre independentemente de função social, de condicionantes estruturais - como a existência de um público - e assim por diante. O pensamento não respeita obediências de nenhuma ordem, tampouco ocorre a alguém de boa vontade em algum momento oportuno. Deleuze, ao tratar da questão do que nos leva a pensar, comenta:

\begin{abstract}
O erro da filosofia é pressupor em nós uma boa vontade de pensar, um desejo, um amor natural pela verdade. A filosofia atinge apenas verdades abstratas que não comprometem, nem perturbam. (...) As ideias da inteligência só valem por sua significação explícita, portanto convencional. Um dos temas em que Proust mais insiste é este: a verdade nunca é o produto de uma boa vontade prévia, mas o resultado de uma violência sobre o pensamento. (...) A verdade depende de um encontro com alguma coisa que nos força a pensar e a procurar o que é verdadeiro. $O$ acaso dos encontros, a pressão das coações são os dois temas fundamentais de Proust. Pois é precisamente o signo que é objeto de um encontro e é ele que exerce sobre nós a violência. $\mathrm{O}$ acaso do encontro é que garante a necessidade daquilo que é pensado. (Deleuze, 2010, p. 14-5)
\end{abstract}

Pensar implica um encontro violento com signos heterogêneos, não é necessário, portanto, obediência ou um círculo de eruditos. Nesse sentido, o pensador privado ou o idiota, operariam uma espécie de contra-pensamento (Deleuze; Guattari, 2008); compreendido como aquele que se afronta com a imagem dogmática de pensamento que estabelece o certo e o errado, o bom e o mau etc. Ora, essa atitude de afronta pode gerar uma certa confusão, pois a noção de privado tenderia a nos fazer acreditar estarmos diante

\footnotetext{
${ }^{4}$ Além disso, trata-se de um binarismo estratégico - como todos os demais presentes nas obras escritas conjuntamente por Deleuze e Guattari -, cuja função é deslocar pontos de referência. Nesse caso, deslocar ou implodir a imagem dogmática de pensamento presente em Kant. Sobre essa estratégia no uso dos dualismos, remetemos o leitor à entrevista concedida por Deleuze à Claire Parnet (Deleuze; Parnet, 2004).
}

(C) ETD-Educação Temática Digital Campinas, SP $\quad$ v.20 $\quad$ n.4 $\quad$ p. 1017-1035 out./dez. 2018 
de alguém que pensa por si só, sozinho e conformado a um campo social - tal qual o uso privado kantiano defendia -, mas não é esse o caso. Sobre as confusões passíveis de serem geradas por essa expressão, lembram-nos os autores (Deleuze; Guattari, 2008):

São os atos [contra-pensamento] de um "pensador privado", por oposição ao professor público: Kierkegaard, Niezsche, ou mesmo Chestov... Onde quer que habitem, é a estepe ou o deserto. Eles destroem as imagens. Talvez o Schopenhauer educador de Nietzsche seja a maior crítica que se tenha feito contra a imagem do pensamento, e sua relação com o Estado. Todavia, "pensador privado" não é uma expressão satisfatória, visto que valoriza uma interioridade, quando se trata de um pensamento do fora. Colocar o pensamento em relação imediata com o fora, com as forças do fora, em suma, fazer do pensamento uma máquina de guerra, é um empreendimento estranho cujos procedimentos precisos pode-se estudar em Nietzsche. (...) Há também uma outra razão pela qual "pensador privado" não é uma boa expressão: pois, se é verdade que esse contrapensamento dá testemunho de uma solidão absoluta, é uma solidão extremamente povoada, como o próprio deserto, uma solidão que já se enlaça a um povo por vir, que invoca e espera esse povo, que só existe graças a ele, mesmo se ele ainda falta... (p. 46)

São outras as coordenadas, portanto; bem como são outras as condições para o exercício do pensar em Deleuze e Deleuze-Guattari. O pensador privado, o idiota e tantos outros contra-pensadores, que se chocam constantemente com a figura do professor público, colocam-nos num espaço no qual o juízo não possuí razão de ser e, nesse espaço, não parece haver lugar para mestres de nenhuma ordem. Mas há um texto, seminal - no sentido em que dá início a distinção entre as personagens conceituais deleuzianas e deleuzo-guattarianas trabalhadas neste texto -, no qual o mestre aparece com uma outra roupagem.

\section{MESTRE}

Gostaríamos, doravante, de nos debruçar sobre o texto deleuziano dedicado à JeanPaul Sartre, "Ele foi meu mestre". Texto menor, talvez, mas ainda assim importante na medida em que, embora apresente muitos elementos comuns à sua filosofia, apresenta uma nova faceta do pensamento de Deleuze. O escrito se inicia da seguinte forma:

Gerações sem "mestres" são uma tristeza. Nossos mestres não são apenas os professores públicos, ainda que tenhamos uma grande necessidade de professores. No momento que atingimos a idade adulta, nossos mestres são aqueles que sabem inventar uma técnica artística ou literária e encontrar as maneiras de pensar que correspondem à nossa modernidade, quer dizer, tanto às nossas dificuldades como aos nossos entusiasmos difusos. (Deleuze, 2006, p. 108) 
O filósofo inicia reconhecendo a necessidade que temos de mestres, mas não no sentido corriqueiro de um professor público - embora esses também possam ser considerados mestres de alguma forma. Os mestres deleuzianos são aqueles que, respondendo ao seu tempo presente, não recorreram a um alhures para pensá-lo, mas criaram uma nova técnica que os possibilitassem problematizar a modernidade em que vivem. Nesse sentido, Kant, ao menos para Foucault, foi um mestre digno de consideração. Assim como Sartre para Deleuze: "os novos temas, um certo estilo novo, uma nova maneira polêmica e agressiva de levantar os problemas, tudo isso veio de Sartre" (Deleuze, 2006, p. 108).

Poder-se-ia objetar que essa concepção de professor público se distingue daquelas ulteriores. Pode o ser, mas, caso continuemos pelo texto em questão, poderemos perceber que a distinção entre esse personagem e o do pensador privado já aparecia de uma maneira bem formatada.

\begin{abstract}
Os "pensadores privados" opõem-se, de uma certa maneira, aos "professores públicos". (...) Os pensadores privados têm duas características: uma espécie de solidão que permanece como propriamente sua em qualquer circunstância; mas também uma certa agitação, uma certa desordem do mundo, na qual eles surgem e falam. Além do mais só falam em seu próprio nome, sem "representar" nada; e solicitam presenças brutas no mundo, potências nuas que de modo algum são "representáveis". (Deleuze, 2006, p. 108)
\end{abstract}

Conforme depreendemos do excerto supramencionado, o pensador privado é aquele em dissonância com o seu mundo. Solitário, não pertence a nenhuma comunidade e tampouco integra um público, como o gostaria Kant, mesmo que isso não seja propriamente verdade. É um contra-pensador, recuperando a terminologia de Mil Platôs.

A grande questão que esse texto de 1964 ajuda-nos a esclarecer, parece-nos, é que pensador privado e professor público não são circunstâncias voluntárias, mas experimentações involuntárias. Ninguém opta por ser um pensador privado em detrimento de um professor público, mas haveria uma certa desordem que, ao encontrar alguém, demandaria o surgimento dessas figuras. A imanência dos encontros assim o exige.

Como, em um diapasão deleuziano e deleuzo-guattariano, a aprendizagem e a criação conceitual dependem dos signos que nos forçam a pensar, apenas quando os experimentamos é que podemos acessar uma outra ordem de pensamento, marcada pela figura do pensador privado. Por vezes criamos um conceito, ou assim acreditamos. Soa inovador, incrível e capaz de problematizar um estado de coisas de maneira inaudita. Porém, muitas vezes sem o perceber, esse conceito surge carregado de valores morais. Ora, é o professor público falando em nós. Outras vezes, tal qual um simples escrivão em Wall

(C) ETD-Educação Temática Digital Campinas, SP $\quad$ v.20 $\quad$ n.4 $\quad$ p.1017-1035 out./dez. 2018


Street ou tal qual Sartre o fez, ousamos pronunciar um sibilo qualquer, algo da ordem de um "preferiria não", e o mundo desaba, este seria o momento no qual o pensador privado atuaria. Assim como pensar e criar são atos involuntários, a presença dessas personagens conceituais também o é. Não podemos prever de antemão se aquilo que intuímos criar será obra de um professor público ou de um pensador privado, por esse motivo só nos resta experimentar. E disso decorre a importância do mestre.

Sartre foi considerado por Deleuze um mestre pois conseguiu, ao recusar toda e qualquer ordem representativa com sua obra e seus gestos, deslocar a filosofia para o mundo do pré-judicativo, ou seja, recusou a esfera do juízo em prol de experimentações de muitas ordens. Sartre, nesse sentido, é o homem que recusa a ordem moral, não se conformando à desordem com a qual depara, e ousa pensar livremente. Algo que outros de sua geração - Deleuze cita Maurice Merleau-Ponty e Albert Camus - não o fizerem de acordo com a leitura deleuziana. Por vagar só e extrair um modo outro de problematizar o seu mundo, Sartre foi um mestre.

Sua obra [Sartre] é uma reação ao mundo burguês, tal como o comunismo o põe em questão. Ela exprime o ultrapassamento de sua própria situação de intelectual burguês, de ex-aluno da École Normale, de noive livre, de homem feio (já que Sartre se apresentava frequentemente assim)... etc.: tudo isso que se reflete e ecoa no movimento de seus livres. (Deleuze, 2006, p. 109)

A maestria é conferia a Sartre por Deleuze por conta de aquele ter conseguindo criar outros espaços de experiência para si, ao fugir da ordem representativa imposta pela moral. Nem um intelectual burguês, nem um homem feio e assim por diante, mas, em confronto com tudo isso, uma coisa outra. Um novo horizonte de pensamento abriu-se a partir de Sartre, um horizonte pré-judicativo e subrepresentativo (Deleuze, 2006), possibilitado por um mero - e violento - encontro com signos heterogêneos. Nesse espaço, cabe a um vivente vagar só apenas. A solidão do mestre é aquela de alguém que se recusa a compactuar com qualquer ordem natural das coisas ou com qualquer valor eterno e, por esse motivo, leva-o a recusar proferir suas sentenças como se fossem uma tábua de valores. Muitos o procuram, pois há a "solidão dos que buscam um mestre" (Deleuze, 2006, p. 109), mas ele se desvencilha - ao ponto de recusar o Nobel que lhe foi ofertado. O mestre, ao fim, não passa de um idiota.

Mengue (2013), recuperando a raiz etimológica da palavra idiota, lembra-nos que esse termo remete aos conceitos de singular, particular, único e, por fim, alguém que se define por si próprio. O comentador, ademais, nota o quanto esse personagem possui uma íntima relação com o pensador privado, aquele que, por forças inatas, cria os seus próprios conceitos e, assim, seu singular modo de ser. Os conceitos, por serem também modos de

C ETD-Educação Temática Digital $\quad$ Campinas, SP $\quad$ v.20 $\quad$ n.4 $\quad$ p. 1017-1035 out./dez. 2018


existência, podem expressar a idiotice ou a maneira singular típica de um pensador privado, de um mestre. Sartre, para Deleuze, apresentou-nos tudo isso e, ao mesmo tempo, recusou conferir a sua idiotice um valor universal, recusou o papel de guru.

O mestre, por fim, é aquele que involuntariamente, ou a partir de seu próprio aprendizado, possibilita-nos vislumbrar a possibilidade de vivenciar um pensamento outro, não judicativo, e, ao mesmo tempo, o faz tudo isso a partir de seu silêncio. O mestre não comunica, não julga, não explica, não representa e por aí afora, ele se cala. Sua tarefa é ética e estética, visa acabar com a ordem moral do mundo, coercitiva e opressora, e oferecer um vislumbre de um real-outro, mas sem com isso ofertar uma tábua de valores a ser seguida por todos. O mestre, por conseguinte, é um pensador privado, um idiota que ousou pensar e viver toda a potência de seu pensamento, que nada nos ensina, apenas nos dá mostras de um possível outro. Não o podemos seguir, não podemos fazer como ele, mas com ele tudo se torna possível.

\section{CONSIDERAÇÕES FINAIS}

Os estudos de acento deleuziano e deleuzo-guattariano em Educação buscam pensar espaços educacionais outros, nos quais o pensamento possa se exercer livremente e aproximar-se da vida, potencializando-a. Um mundo pré-judicativo, no qual vigora uma concepção amoral de Educação: não há bom e mau, tampouco verdadeiro e falso, há apenas experimentações. Essas são avaliadas conforme a sua potência, o seu poder de afetar. Nesse diapasão, concepções tradicionais como as de ensino-aprendizado acabam transmutando-se e recebem um outro nuançado. Sobre o aprender, Deleuze (1988) nos lembra que:

Nada aprendemos com aquele que nos diz: faça como eu. Nossos únicos mestres são aqueles que nos dizem "faça comigo" e que, em vez de nos propor gestos a serem reproduzidos, sabem emitir signos a serem desenvolvidos no heterogêneo. (...) Aprender é constituir esse espaço do encontro com signos. (p. 48-9)

Mais uma vez deparamos com a figura do mestre, apresentado como aquele que diz "faça comigo". Fazer com alguém, ou aprender com alguém, não significa replicar o que esse alguém fez, tomar a lição como uma verdade digna de ser seguida ao pé-da-letra, mas produzir um espaço no qual mestre e aluno possam se afetar. Espaço de liberdade, no qual noções como uso público ou uso privado da razão não fazem sentido algum, pois vigora ali uma concepção de companhia. O mestre é um companheiro no processo de experimentação, não diz o que devemos fazer, mas nos lembra que outros espaços de experiência, mais potentes, são possíveis.

C ETD- Educação Temática Digital Campinas, SP $\quad$ v.20 $\quad$ n.4 $\quad$ p.1017-1035 out./dez. 2018 
Não podemos, portanto, abandonar essa importante concepção da mestria, por a acreditarmos autoritária ou anacrônica. Os mestres são personagens importantíssimos no interior do universo deleuziano do aprendizado, desde que sejam tomados como pensadores privados ou idiotas. Acabar com os juízos, eliminar a distinção entre o verdadeiro e o falso e o bom e o mau, poderia nos levar a querer abolir certas relações historicamente marcadas por certo tom judicativo - como a do mestre-aprendiz -, mas Deleuze, que sempre defendeu que as relações são exteriores aos termos que comporta, parece-nos lembrar que não se trata disso. Não é eliminando a figura do mestre que escapamos de um mundo judicativo, pois a ausência de mestres, muitas vezes, pode descambar num autoritarismo sem precedentes. A questão é buscar uma outra relação com essa figura, relação esta que não esteja assentada num campo crítico, tal qual o quer Kant, responsável por estabelecer, para que seja possível a saída do homem de sua menoridade, a necessidade de condicionantes para que o exercício do pensamento possa ocorrer. Menos crítica e mais clínica, parece querer nos ensinar Deleuze.

\section{REFERÊNCIAS}

CASTELLO, Luis A.; MÁRSICO, Claudia T. Oculto nas palavras - dicionário etimológico para ensinar e aprender. Belo Horizonte: Autêntica, 2007.

DELEUZE, Gilles. Diferença e Repetição. Tradução de Roberto Machado e Luiz B. Orlandi. São Paulo: Graal, 1988.

DELEUZE, Gilles. "Ele foi meu mestre". In: DELEUZE, Gilles. A Ilha Deserta e outros textos. Tradução de Francisca Maria Cabrera. São Paulo: lluminuras, 2006d. p. 107-110.

DELEUZE, Gilles. Nietzsche e a filosofia. Tradução: Edmundo Fernandes Dias e Ruth Jofflily Dias. Rio de Janeiro: Editora Rio, 1976.

DELEUZE, Gilles. "Para dar um fim no juízo". In: DELEUZE, Gilles. Crítica e Clínica. Tradução Peter Pál Pelbart. São Paulo: Editora 34, 2007. p. 143-153.

DELEUZE, Gilles. Proust e os signos. Tradução de Antônio Carlos Piquet e Roberto Machado. Rio de Janeiro: Forense Universitária, 2010.

DELEUZE, Gilles; GUATTARI, Félix. Mil Platôs: capitalismo e esquizofrenia, vol. 5. Tradução de Peter Pál Pelbart e Janice Caiafa. São Paulo: Editora 34, 2008.

DELEUZE, Gilles; GUATTARI, Félix. $\mathbf{O}$ que é a Filosofia? Tradução de Bento Prado Jr. e Alberto Alonso Muñoz. São Paulo: Editora 34, 1992. 
DELEUZE, Gilles; PARNET, Claire. Diálogos. Tradução de José Gabriel Cunha. Lisboa: Relógio D’Água, 2004.

FOUCAULT, Michel. "O que são as Luzes?". In: FOUCAULT, Michel. Ditos \& Escritos II: arqueologia das ciências e história dos sistemas de pensamento. organização de manual Barros da Motta. Rio de Janeiro: Forense Universitária, 2008. p. 335-351.

GALLO, Silvio. "As múltiplas dimensões do aprender..." In: Anais do Congresso de Educação Básica: aprendizagem e currículo, Florianópolis, n.1, 2012. p. 1-10.

KANT, Immanuel. "O que é o Esclarecimento?". In: KANT, Immanuel et al. O que é o Esclarecimento? Tradução de Paulo César Gil Ferreira. Rio de Janeiro: Via Verita, 2011. p. 23-36.

LINS, Daniel. Juízo e Verdade em Gilles Deleuze. Tradução de Fabien Lins. São Paulo: Annablume, 2004.

MARINHO, Cristiane Maria. Filosofia e Educação no Brasil: da identidade à diferença. São Paulo: Edições Loyola, 2014.

MENGUE, Philippe. Faire L'idiot: la politique de Deleuze. Paris: Germina, 2013.

SCHÉRER, René. "Aprender com Deleuze". In: Educação \& Sociedade, Campinas, v. 26, n. 93, p. 1183-1194, Set-Dez. 2005.

VINCl, Christian Fernando Ribeiro Guimarães. Deleuze-Guattarinianas: experimentações educacionais com o pensamento de Gilles Deleuze e Félix Guattari (1990-2013). Dissertação de mestrado. São Paulo: Universidade de São Paulo, 2014.

VINCl, Christian Fernando Ribeiro Guimarães. "Humorística e sensibilidade filosófica em Gilles Deleuze". In: Prometeus - filosofia em revista, Sergipe, v. 10, n. 23. 2017. p. 167-187.

\section{Agradecimentos}

Agradecemos à Fundação de Apoio à Pesquisa do Estado de São Paulo (FAPESP) pelo financiamento, do qual resultou esse trabalho. 